\title{
A Comparative Study of Raw and Metal Oxide Impregnated Carbon Nanotubes for the Adsorption of Hexavalent Chromium from Aqueous Solution
}

\author{
Muhammad I. Qureshi, ${ }^{1}$ Faheemuddin Patel, ${ }^{2}$ Nadhir Al-Baghli, ${ }^{1}$ Basim Abussaud, \\ Bassam S. Tawabini, ${ }^{3}$ and Tahar Laoui ${ }^{2}$ \\ ${ }^{1}$ Department of Chemical Engineering, KFUPM, Dhahran 31261, Saudi Arabia \\ ${ }^{2}$ Department of Mechanical Engineering, KFUPM, Dhahran 31261, Saudi Arabia \\ ${ }^{3}$ Department of Geosciences, KFUPM, Dhahran 31261, Saudi Arabia \\ Correspondence should be addressed to Tahar Laoui; tlaoui@kfupm.edu.sa
}

Received 13 February 2017; Revised 12 March 2017; Accepted 16 March 2017; Published 10 April 2017

Academic Editor: Viktor Kochkodan

Copyright ( 2017 Muhammad I. Qureshi et al. This is an open access article distributed under the Creative Commons Attribution License, which permits unrestricted use, distribution, and reproduction in any medium, provided the original work is properly cited.

The present study reports the use of raw, iron oxide, and aluminum oxide impregnated carbon nanotubes (CNTs) for the adsorption of hexavalent chromium $(\mathrm{Cr}(\mathrm{VI})$ ) ions from aqueous solution. The raw $\mathrm{CNTs}$ were impregnated with $1 \%$ and $10 \%$ loadings (weight \%) of iron oxide and aluminum oxide nanoparticles using wet impregnation technique. The synthesized materials were characterized using scanning electron microscopy (SEM) and thermogravimetric analysis (TGA). Batch adsorption experiments were performed to assess the removal efficiency of $\mathrm{Cr}(\mathrm{VI})$ ions from water and the effects of $\mathrm{pH}$, contact time, adsorbent dosage, and initial concentration of the $\mathrm{Cr}(\mathrm{VI})$ ions were investigated. Results of the study revealed that impregnated CNTs achieved significant increase in the removal efficiency of $\mathrm{Cr}(\mathrm{VI})$ ions compared to raw CNTs. In fact, both CNTs impregnated with $10 \%$ loading of iron and aluminum oxides were able to remove up to $100 \%$ of $\mathrm{Cr}(\mathrm{VI})$ ions from aqueous solution. Isotherm studies were carried out using Langmuir and Freundlich isotherm models. Adsorption kinetics of $\mathrm{Cr}(\mathrm{VI})$ ions from water was found to be well described by the pseudo-second-order model. The results suggest that metallic oxide impregnated CNTs have very good potential application in the removal of $\mathrm{Cr}(\mathrm{VI})$ ions from water resulting in better environmental protection.

\section{Introduction}

Chromium is mainly found in natural deposits as ores and other compounds such as chrome ochre $\left(\mathrm{Cr}_{2} \mathrm{O}_{3}\right)$, crocoite $\left(\mathrm{PbCrO}_{4}\right)$, and ferric chromite $\left(\mathrm{FeCr}_{2} \mathrm{O}_{4}\right)$. It is the sixth most abundant transition metal $[1,2]$. Chromium is discharged into water bodies from a number of industrial sources such as electroplating and metal cleaning, leather tanning, mining of chrome ore, production of steel and alloys, dyes and pigments, glass industry, wood preservation, and textile industry [2-5].

Chromium is found in different oxidation states such as $2+, 3+$, and $6+$. In water, it can exist in the form of chromate ion $\left(\mathrm{CrO}_{4}{ }^{2-}\right)$, chromic acid $\left(\mathrm{H}_{2} \mathrm{CrO}_{4}\right)$, hydrogen chromate ion $\left(\mathrm{HCrO}_{4}^{-}\right)$, and dichromate ion $\left(\mathrm{Cr}_{2} \mathrm{O}_{7}{ }^{2-}\right)$ [6-8]. However, the hexavalent $\mathrm{Cr}(\mathrm{VI})$ and trivalent $\mathrm{Cr}(\mathrm{III})$ are the two most stable forms present in water in neutral $\mathrm{pH}$ range.

The typical concentration of chromium in industrial water ranges from 5.2 to $208,000 \mathrm{mg} / \mathrm{L}[9,10]$. The maximum allowable limits of chromium in drinking water are 0.05 and $0.1 \mathrm{mg} / \mathrm{L}$, as suggested by the World Health Organization (WHO) and US Environmental Protection Agency (EPA), respectively [11-15].

Due to its carcinogenic and mutagenic nature, $\mathrm{Cr}(\mathrm{VI})$ is considered as almost 300 times more toxic than $\mathrm{Cr}$ (III) [16]. The toxic effects of $\mathrm{Cr}(\mathrm{VI})$ include liver and kidney damage, nausea, dermatitis, diarrhea, vomiting, internal hemorrhage, 
and repository problems (asthma). Eye and skin contact may cause permanent damage to eye, severe burn, irritation, ulceration, and nasal septum $[17,18]$.

A number of remediation techniques have been reported to get rid of the $\mathrm{Cr}(\mathrm{VI})$ from water including solvent extraction [19], floatation [20], coagulation [21], ion exchange [22-25], membrane technologies [26, 27], adsorption $[6,7,28]$ and cyanide treatment [29], and reduction followed by chemical precipitation [30]. However, adsorption is the most versatile, cost effective, and widely used method for removal of different contaminants from water including heavy metals. In the literature, different adsorbents have been reported for the removal of $\mathrm{Cr}(\mathrm{VI})$ from water including anaerobic sludge [31], lignocellulosic solid wastes [32], carbon slurry [33], waste slurry [34], agricultural wastes [35], cow dung carbon [36], corncob [37], almond shell carbon [38], zeolite [39], hazelnut shell carbon [40, 41], rice Polish [42], sphagnum moss peat [43], apple residue [44], moss [45], rice husk carbon [46], fly ash [6, 47], pine needles, charcoal, wool, olive stone/cake, cactus [48], used tyre carbon [49], coconut tree sawdust carbon [50], sawdust [51], dust coal, coconut shell and wood activated carbons [52], clay [53], palm pressed fibers and coconut husk [54], activated groundnut husk carbon [55], polyaniline coated on sawdust [56], coniferous leaves [57], leaf mould [58], wheat bran [59], sugar beet pulp [60], seaweeds [61], tannin gel particles [62], seaweed biosorbent [63], chitosan-1,2-cyclohexylenedinitrilotetraacetic acid-graphene oxide (Cs/CDTA/GO) nanocomposite [64], paper mill sludge [65], hydrous concrete particles [66], waste tea [67], activated alumina, rice husk ash, neem bark, saw dust, fuller's earth [6], eucalyptus bark, activated charcoal, and charred rice husk [68], treated waste newspaper [69], and graphene oxide (GO) [70].

Recently, carbon nanotubes (CNTs) have emerged as a novel adsorbent for the removal of various contaminants from water. CNTs offer the advantages of high porous and hallow structure, light mass density, large surface, and strong interaction with the pollutant molecules [28]. Studies have confirmed that surface modification of CNTs significantly enhanced their adsorption capability for the removal of various contaminants from water [71-76].

In the present study, raw CNTs and CNTs impregnated with iron oxide and aluminum oxide nanoparticles were used for the adsorption of $\mathrm{Cr}(\mathrm{VI})$ from water. The synthesized materials were characterized using scanning electron microscopy (SEM) and thermogravimetric analysis (TGA). Batch adsorption experiments were performed and the effect of $\mathrm{pH}$, contact time, adsorbent dosage, and initial concentration of the adsorbate on the removal efficiency of $\mathrm{Cr}(\mathrm{VI})$ from water was investigated. Isotherm studies were carried out using Langmuir and Freundlich isotherm models.

\section{Experimental}

2.1. Materials Preparation. Raw CNTs were acquired from Chengdu Organic Chemicals Co. Ltd. (China), with the following characteristics: $95 \%$ purity, outside diameter of $10-20 \mathrm{~nm}$, and length ranging from 1 to $10 \mu \mathrm{m}$. These raw
CNTs were impregnated with $1 \%$ and $10 \%$ loadings (weight $\%$ ) of iron oxide and aluminum oxide nanoparticles using wet impregnation technique. Specific amount of CNTs was added in ethanol and sonicated to achieve homogenous dispersion of CNTs. Specific amount of metallic salt dissolved separately in ethanol and was sonicated, and then the resultant solution was added dropwise to the CNTs dispersed in ethanol. This dispersion was sonicated for proper mixing with CNTs and subsequently heated at $80-90^{\circ} \mathrm{C}$ in an oven overnight to evaporate the ethanol. On complete drying, the CNTs were calcined in a furnace at $350^{\circ} \mathrm{C}$ for 4 hours. This process resulted in the attachment of metal oxide nanoparticles onto the surface of CNTs.

2.2. Characterization of the Adsorbents. Raw and impregnated CNTs were characterized using various techniques. In order to perform morphological and elemental analysis, samples were coated with about $5 \mathrm{~nm}$ thick layer of platinum using Quorum sputter coater (Model: Q150R S). Scanning electron microscope (Model: TESCAN MIRA 3 FEG-SEM) was used to analyze the morphology and structure of raw and metal oxide impregnated CNTs. Thermogravimetric analysis (TGA) of raw and impregnated CNTs was performed using TA Instrument (Model: SDTQ600), in order to evaluate the purity and thermal degradation of materials. Samples were heated to $900^{\circ} \mathrm{C}$ in air, at heating rate of $10^{\circ} \mathrm{C} / \mathrm{min}$ and air flow rate of $100 \mathrm{~mL} / \mathrm{min}$.

2.3. Batch-Mode Adsorption Experiment. Batch experiments were performed to study the effect of various parameters on the adsorption of $\mathrm{Cr}(\mathrm{VI})$ ions by raw and metal oxide impregnated CNTs at room temperature.

The effect of $\mathrm{pH}$, contact time, agitation speed, and adsorbent dosage was investigated on the removal of $\mathrm{Cr}(\mathrm{VI})$ ions from aqueous solution. Concentration of $\mathrm{Cr}(\mathrm{VI})$ ions was measured using inductively coupled plasma mass spectrometer (Thermo-Fisher, X-Series 2 Q-ICP-MS).

Percentage removal and adsorption capacity were calculated using (1) and (2), respectively:

$$
\begin{aligned}
& \text { Removal efficiency }(\%)=\frac{C_{o}-C_{t}}{C_{o}} * 100 \\
& \text { Adsorption capacity }(q)=\frac{\left(C_{o}-C_{t}\right) V}{m},
\end{aligned}
$$

where " $C_{o}$ " is the initial concentration (ppm) at start of the experiment $(t=0)$, while " $C_{t}$ " is the concentration at time " $t$ ". " $V$ " is the volume $(\mathrm{L})$ of the solution and " $m$ " represents the amount ( $g$ ) of the adsorbent dosage. For the batch adsorption experiments, the stock solution was prepared using the same methodology reported previously [73].

\section{Results and Discussion}

3.1. Characterization of Raw and Metal Oxide Impregnated CNTs. Surface morphologies of the raw and metal oxide impregnated CNTs were observed using SEM. 


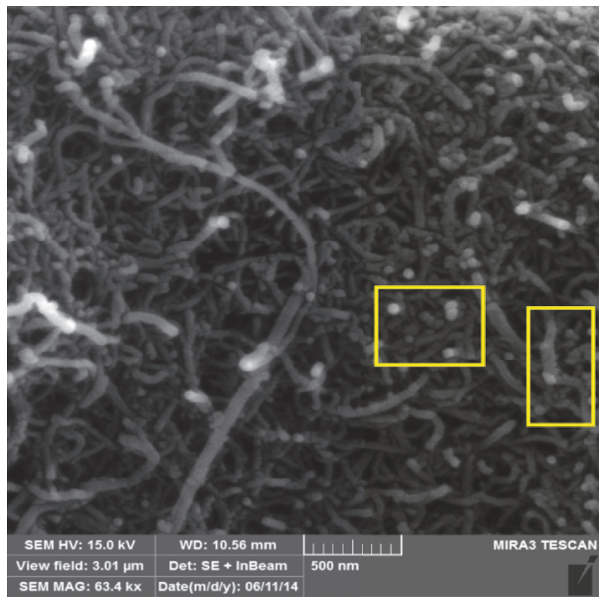

(a)

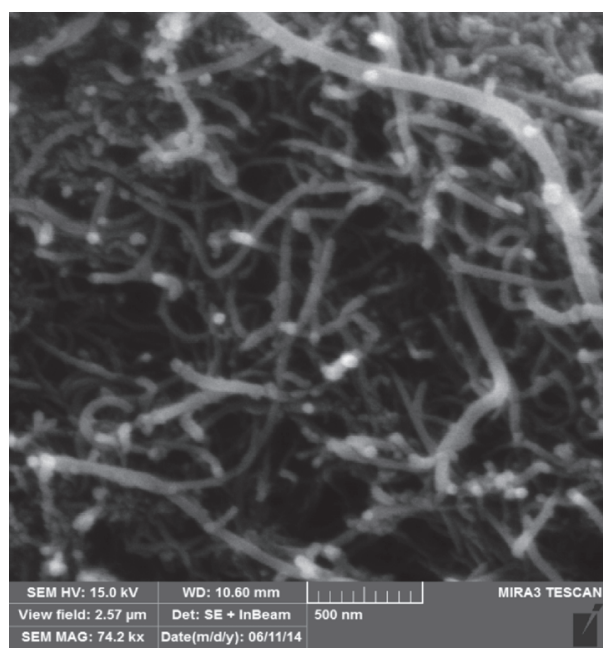

(c)

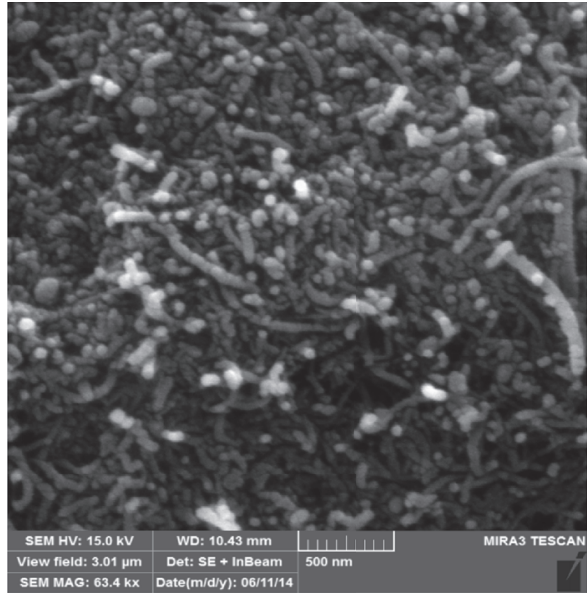

(b)

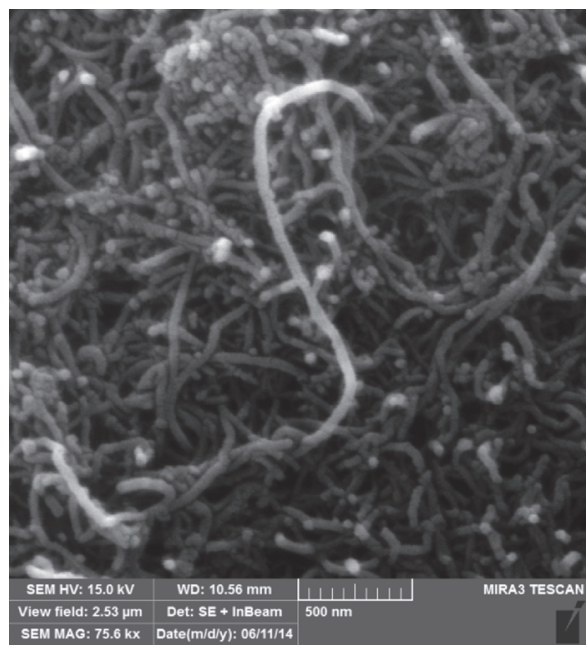

(d)

FIGURE 1: SEM images of CNTs with (a) 1\% iron oxide (boxes indicate the iron oxide nanoparticles impregnated on CNTs), (b) $10 \%$ iron oxide, (c) $1 \%$ aluminum oxide, and (d) $10 \%$ aluminum oxide.

Figure 1 shows the SEM images for the metal oxides impregnated CNTs. Tubular geometry of the CNTs was observed and no damage was noticed in CNTs structures after impregnation. Metal oxide nanoparticles (highlighted in the box) were clearly observed on the surface of CNTs as displayed in Figures 1(a)-1(d). CNTs were properly dispersed for the low loading of $1 \%$ metal oxide (Figures $1(\mathrm{a})$ and 1(c)); however, at higher loading (10\%) a little agglomeration of metal oxide particles could be seen in Figures 1(b) and 1(d). In general, the dispersion of CNTs was improved after impregnation with metal oxide nanoparticles. Metal oxide nanoparticles might help reduce the strong Van der Waals forces between CNTs leading to their improved dispersion.

TGA curves for raw and metal oxide impregnated CNTs are presented in Figure 2. CNTs were heated to $900^{\circ} \mathrm{C}$ at a rate of $10^{\circ} \mathrm{C} / \mathrm{min}$ under air. All the TGA curves have two main weight loss regions. Initial small weight loss was attributed to the evaporation of physically bound water and some other lighter impurities. The second, steep, and rapid weight loss region represents the combustion of CNTs. Raw CNTs showed more stability and started degrading around $550^{\circ} \mathrm{C}$ while degradation of $1 \%$ and $10 \%$ metal oxide impregnated CNTs started around $450^{\circ} \mathrm{C}$ and $500^{\circ} \mathrm{C}$, respectively. This may be due to the fact that the impregnation of metal oxide nanoparticles on CNTs serves as an impurity hence leading to steep weight loss at lower temperature [77]. The weight of the residue left at the end of the analysis is the indication of metallic oxide nanoparticles. It can be observed that the amount of residue left was higher for the CNTs with $10 \%$ metal oxide loading as compared to raw CNTs and CNTs with $1 \%$ metal oxide loadings.

3.2. Effect of $p H$. The removal of $\mathrm{Cr}(\mathrm{VI})$ ions by raw and metal oxide impregnated CNTs, as a function of $\mathrm{pH}$, is presented in Figure 3. Solution $\mathrm{pH}$ was varied from 3 to 8 , while the other variables including adsorbent dosage, contact time, agitation speed, and $\mathrm{Cr}(\mathrm{VI})$ initial concentration were kept constant at $200 \mathrm{mg}, 2$ hours, $50 \mathrm{mg}, 200 \mathrm{rpm}$, and $1 \mathrm{mg} / \mathrm{L}$, respectively.

A maximum removal of $\mathrm{Cr}(\mathrm{VI})$ was achieved at $\mathrm{pH} 3$, while the removal was observed to decrease with increase in 


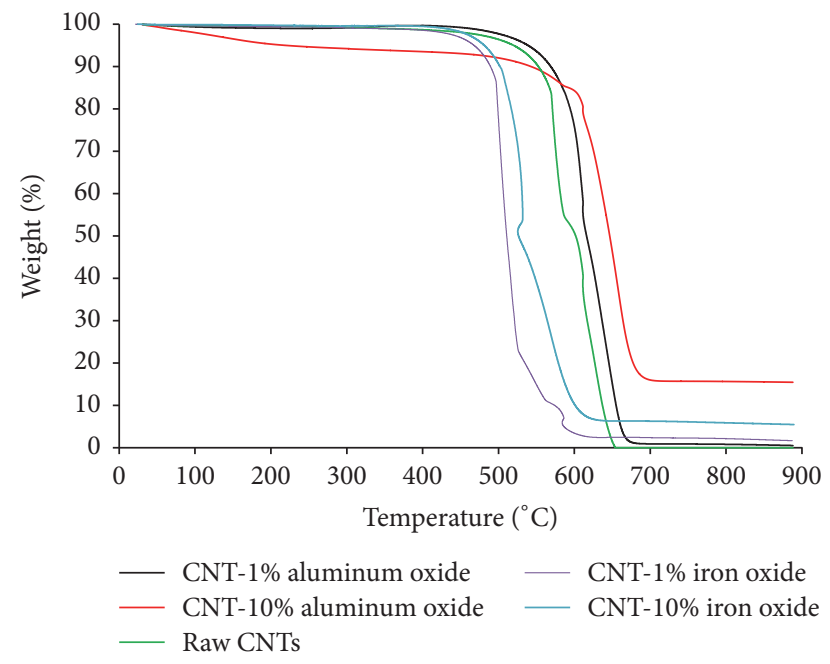

FIGURE 2: TGA curves for raw and metal oxide impregnated CNTs.

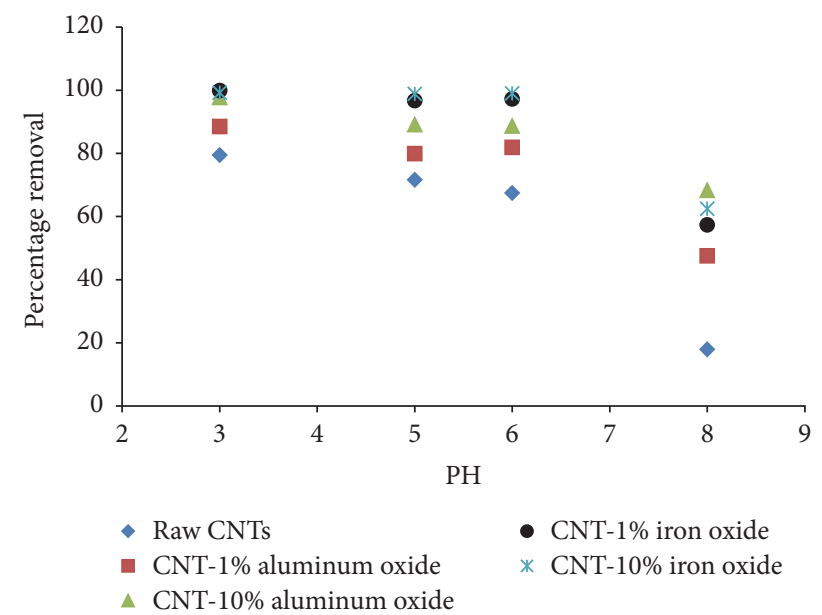

FIgURE 3: Effect of $\mathrm{pH}$ on the percentage removal of $\mathrm{Cr}(\mathrm{VI})$ (initial concentration $=1 \mathrm{mg} / \mathrm{L}$, agitation speed $=200 \mathrm{rpm}$, adsorbent dosage $=200 \mathrm{mg}$, and time $=2$ hours).

$\mathrm{pH}$, for all the adsorbents. This phenomenon can be explained on the basis of surface charge of the adsorbents and ionic chemistry of the solution.

Chromium ions may exist in the form of chromate $\left(\mathrm{CrO}_{4}{ }^{2-}\right)$, dichromate $\left(\mathrm{Cr}_{2} \mathrm{O}_{7}{ }^{2-}\right)$, and hydrogen chromate $\left(\mathrm{HCrO}_{4}{ }^{-}\right)$, depending upon the solution $\mathrm{pH}$ and chromate concentration.

The equilibrium between the chromate $\left(\mathrm{CrO}_{4}{ }^{2-}\right)$ and dichromate ions $\left(\mathrm{Cr}_{2} \mathrm{O}_{7}{ }^{2-}\right)$ in aqueous solution is represented by $(3)[15,73]$.

$$
2 \mathrm{CrO}_{4}{ }^{2-}+2 \mathrm{H}^{+} \longleftrightarrow \mathrm{Cr}_{2} \mathrm{O}_{7}^{2-}+\mathrm{H}_{2} \mathrm{O}
$$

Chromate $\left(\mathrm{CrO}_{4}{ }^{2-}\right)$ ions are the dominant species at high $\mathrm{pH}$ values, while, at low $\mathrm{pH}$, mainly dichromate ions $\left(\mathrm{Cr}_{2} \mathrm{O}_{7}{ }^{2-}\right)$ exist in the solution $[78,79]$.

At low $\mathrm{pH}$, the high removal of $\mathrm{Cr}(\mathrm{VI})$ ions is attributed to the electrostatic interaction between the $\mathrm{Cr}_{2} \mathrm{O}_{7}{ }^{2-}$ anions and positively charged CNTs surface. However, at high

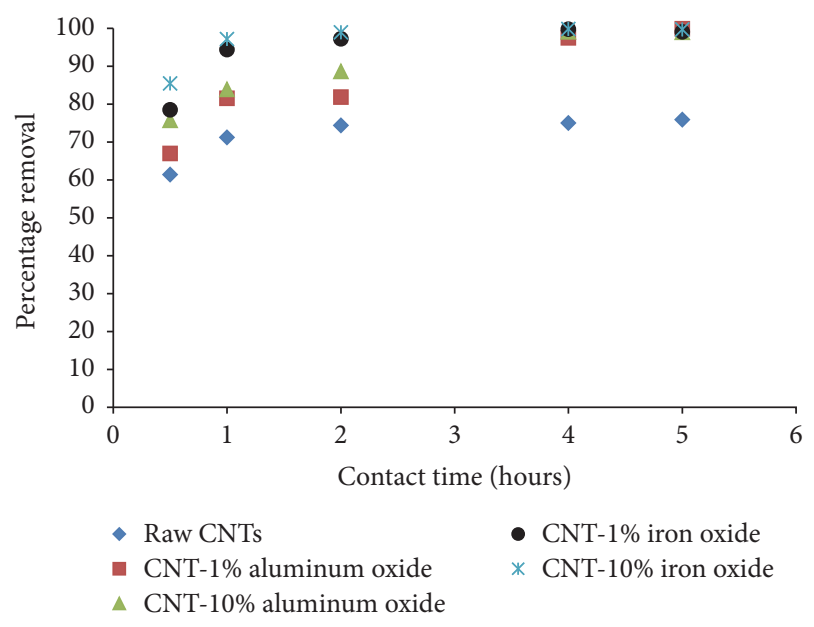

FIGURE 4: Effect of contact time on percentage removal of $\mathrm{Cr}(\mathrm{VI})$. (Initial concentration $=1 \mathrm{mg} / \mathrm{L}$, agitation speed $=200 \mathrm{rpm}$, adsorbent dosage $=200 \mathrm{mg}, \mathrm{pH}=6$ ).

$\mathrm{pH}$, surfaces of the CNTs carry more negative charges and repulsion between the $\mathrm{CrO}_{4}{ }^{2-}$ ions and the CNTs surfaces resulted in lower removal of $\mathrm{Cr}(\mathrm{VI})$ ions. Furthermore, the low removal might also be due to competition between the $\mathrm{OH}^{-}$and chromate $\left(\mathrm{CrO}_{4}{ }^{2-}\right)$ ions over the limited adsorption sites as well as due to precipitation of $\mathrm{Cr}(\mathrm{OH})_{3}$ that might occur at high $\mathrm{pH}($ here at $\mathrm{pH}=8)$ [73].

Surface impregnation of CNTs with metal oxide was observed to enhance the removal efficiency. The maximum removal of $87.8 \%$ was obtained for CNT with $10 \%$ aluminum oxide loading at $\mathrm{pH}$ 3. Raw CNTs were still able to remove almost $74 \% \mathrm{Cr}(\mathrm{VI})$ ions at same $\mathrm{pH}$ and under similar experimental conditions. Although the maximum removal was obtained at $\mathrm{pH} 3$, however, to evaluate the potential of the adsorbents in real water treatment applications, a $\mathrm{pH}$ value of 6 was selected for the remaining experiments.

Because the solution $\mathrm{pH}$ has a significant effect on the removal of $\mathrm{Cr}(\mathrm{VI})$ ions, we may deduce that the main mechanism is electrostatic interaction. The net surface charge of the adsorbent changes with $\mathrm{pH}$ and affects the removal of $\mathrm{Cr}(\mathrm{VI})$. In addition to electrostatic interaction, some physical adsorption of $\mathrm{Cr}(\mathrm{VI})$ ions is expected on the surfaces of the CNTs due to Van der Walls interactions. Studies also suggest that strong surface complexation and ion exchange are the main mechanisms involved during the adsorption of $\mathrm{Cr}(\mathrm{VI})$ ions on CNTs surface [80].

3.3. Effect of Contact Time. The experimental results presenting the effect of time on the removal of $\mathrm{Cr}(\mathrm{VI})$ ions by raw and metal oxide impregnated CNTs are shown in Figure 4. Contact time was varied from 0.5 to 5 hours while the solution $\mathrm{pH}, \mathrm{Cr}(\mathrm{VI})$ initial concentration, adsorbent dosage, and agitation speed were kept constant at 6,1 mg/L, $200 \mathrm{mg}$, and $200 \mathrm{rpm}$, respectively.

It is obvious that $\mathrm{Cr}(\mathrm{VI})$ ions removal has improved significantly as the contact time increased from 0.5 to 4 hours. No significant increase in removal was observed after 4 hours of contact time indicating the reach of equilibrium. 


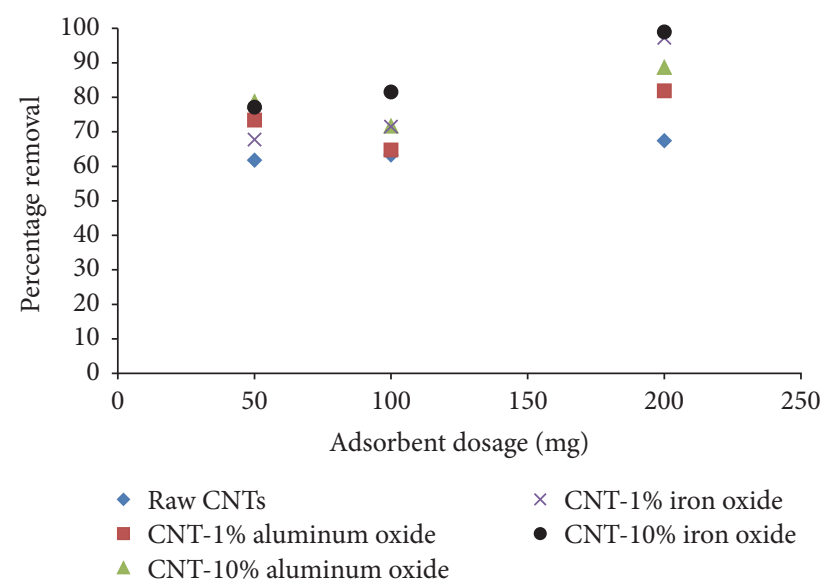

FigURE 5: Effect of adsorbent dosage on percentage removal of $\mathrm{Cr}(\mathrm{VI})$ (initial concentration $=1 \mathrm{mg} / \mathrm{L}$, agitation speed $=200 \mathrm{rpm}$, contact time $=2$ hours, and $\mathrm{pH}=6$ ).

It was observed that CNTs impregnated with metal oxide were able to remove more than $97 \%$ of $\mathrm{Cr}(\mathrm{VI})$ ions after 2 hours of contact time (for CNTs impregnated with iron oxide) and almost $100 \%$ after 4 hours of contact time (for CNTs impregnated with both iron and aluminum oxides).

3.4. Effect of Adsorbent Dosage. The effect of adsorbent dosage on the removal of $\mathrm{Cr}$ (VI) ions is depicted in Figure 5. The adsorbent dosage was varied from 50 to $200 \mathrm{mg}$, while solution $\mathrm{pH}$, contact time, initial concentration of $\mathrm{Cr}(\mathrm{VI})$, and agitation speed were kept constant at 6, 2 hours, $1 \mathrm{mg} / \mathrm{L}$, and $200 \mathrm{rpm}$, respectively.

A direct relationship was observed between the adsorbent dosage and the removal of $\mathrm{Cr}(\mathrm{VI})$ ions for all adsorbents. The removal was observed to increase with increase in the adsorbent dosage and the maximum removal was recorded at $200 \mathrm{mg}$ dosage. With increase in the adsorbent dosage, the number of active sites increases; hence more $\mathrm{Cr}(\mathrm{VI})$ ions can be adsorbed onto the adsorbent surface. At $200 \mathrm{mg}$ dosage, CNTs with $10 \%$ loading of iron oxide yielded a maximum removal of $99 \%$ of $\mathrm{Cr}(\mathrm{VI})$ ions, as compared to raw CNTs yielding about $67 \%$ removal under similar experimental conditions. These results confirmed that metal oxide loading has a significant effect on the removal efficiency of the raw CNTs.

3.5. Effect of Agitation Speed. Agitation speed is an important parameter that effects and enhances the dispersion of the adsorbent in the solution and reduces the agglomeration. For the two loadings of metal oxides (1\% and $10 \%)$ used in the present study, the CNTs were found to properly disperse in the solution and no significant agglomeration was observed. Figure 6 displays the effect of agitation speed on the removal of $\mathrm{Cr}(\mathrm{VI})$ ions by raw and metal oxides impregnated CNTs. The agitation speed was varied from 50 to $200 \mathrm{rpm}$, while the solution $\mathrm{pH}$, initial concentration, adsorbent dosage, and contact time were kept constant at $6,1 \mathrm{mg} / \mathrm{L}, 200 \mathrm{mg}$, and 2 hours, respectively. The removal of $\mathrm{Cr}(\mathrm{VI})$ ions was observed to increase with increase in agitation speed for all considered

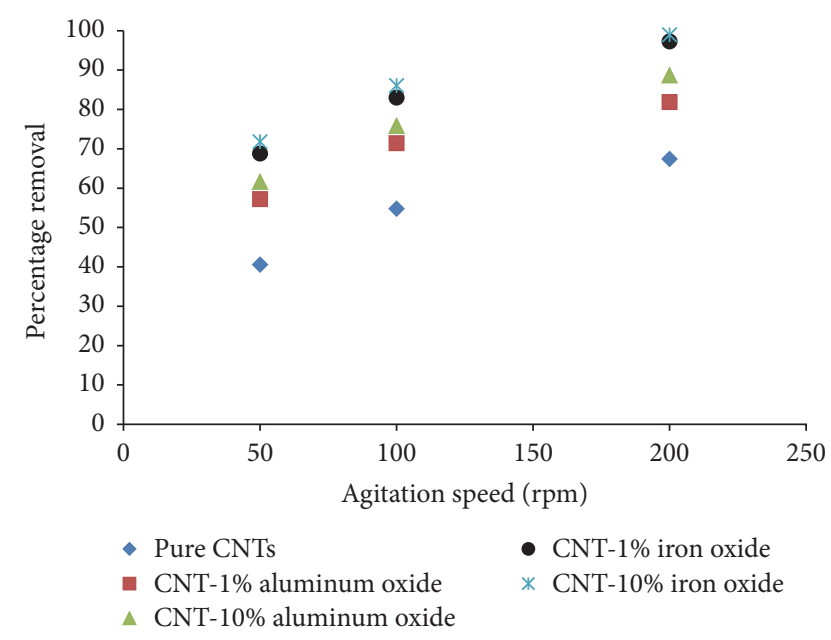

FIGURE 6: Effect of agitation speed on percentage removal of $\mathrm{Cr}(\mathrm{VI})$ ions (initial concentration $=1 \mathrm{mg} / \mathrm{L}$, adsorbent dosage $=200 \mathrm{mg}$, contact time $=2$ hours, and $\mathrm{pH}=6$ ).

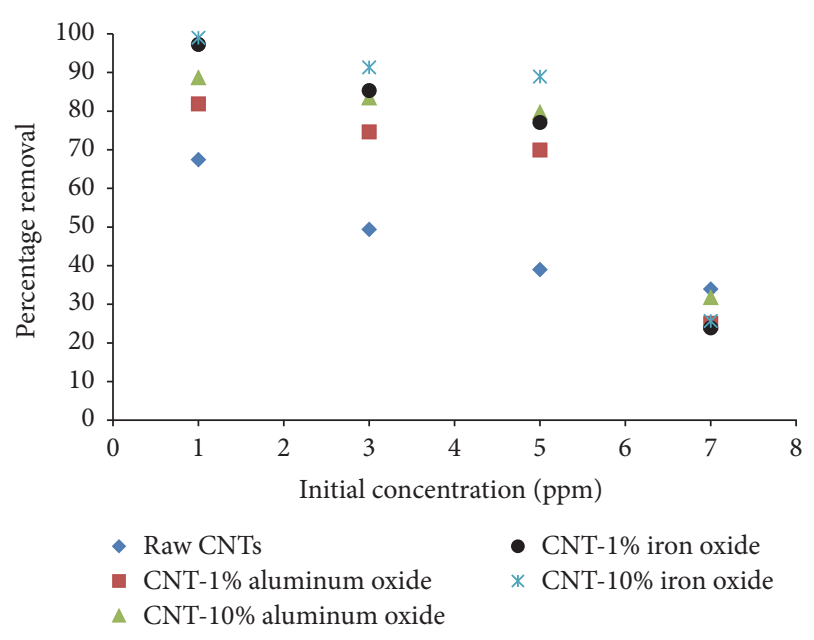

FIGURE 7: Effect of initial concentration on percentage removal of $\mathrm{Cr}(\mathrm{VI})$ (adsorbent dosage $=200 \mathrm{mg}$, contact time $=2$ hours, agitation speed $=200 \mathrm{rpm}$, and $\mathrm{pH}=6$ ).

adsorbents. This is due to the fact that agitation facilitates effective diffusion of ions towards the adsorbent surface [73]. At $200 \mathrm{rpm}$ speed, CNTs with 10\% loading of iron oxide were able to remove $99 \% \mathrm{Cr}(\mathrm{VI})$ ions.

3.6. Effect of Initial Concentration. The removal of $\mathrm{Cr}(\mathrm{VI})$ ions was also dependent on the initial concentration of $\mathrm{Cr}(\mathrm{VI})$ as shown in Figure 7. The initial concentration was varied from 1 to $7 \mathrm{ppm}$, while the solution $\mathrm{pH}$, agitation speed, adsorbent dosage, and contact time were kept constant at 6, $200 \mathrm{rpm}, 200 \mathrm{mg}$, and 2 hours, respectively. The maximum removal was achieved at low dosage concentration and the removal was observed to decrease with increase in concentration for all adsorbents. This might be due to the fact that, at high concentration, the adsorption sites are saturated due to availability of surplus $\mathrm{Cr}(\mathrm{VI})$ ions. At $1 \mathrm{ppm}$ dosage, a maximum removal $99 \%$ of $\mathrm{Cr}(\mathrm{VI})$ ions was achieved with CNTs with $10 \%$ loading of iron oxide. 
TABLE 1: Parameters of Langmuir and Freundlich isotherm models for chromium.

\begin{tabular}{lcccr}
\hline Adsorbent & & Freundlich & \multicolumn{2}{c}{ Langmuir } \\
& $n$ & $K_{F}(\mathrm{~L} / \mathrm{mg})$ & $R^{2}$ & $K_{L}(\mathrm{~L} / \mathrm{mg})$ \\
\hline CNT-iron oxide & 7.922564 & 0.628705 & 0.9980 & -7.47535 \\
CNT-aluminum oxide & 3.907029 & 0.571687 & 0.9996 & -10.9559 \\
Raw CNTs & 2.110755 & 0.291322 & 0.9975 & 0.75656 \\
\hline
\end{tabular}

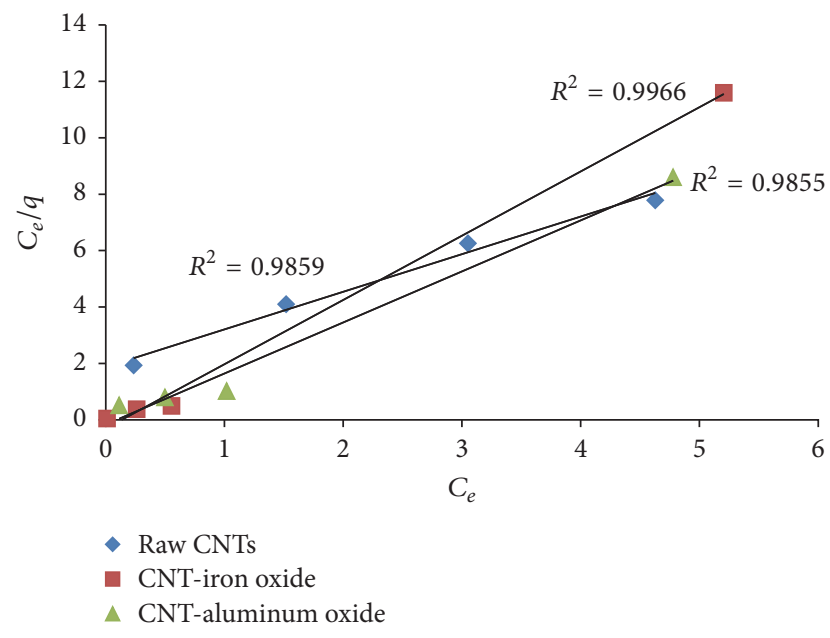

FIGURE 8: Langmuir adsorption model for $\mathrm{Cr}(\mathrm{VI})$.

3.7. Freundlich and Langmuir Isotherm Models. Adsorption equilibrium data was fitted by Langmuir and Freundlich models. Langmuir model best describes the monolayer adsorption while Freundlich model provides information about heterogeneous adsorption on adsorbent surface [81].

Representative equations of the isotherm models are presented below.

Langmuir isotherm model:

$$
q_{e}=\frac{q_{m} K_{L} C_{e}}{1+K_{L} C_{e}}
$$

Freundlich isotherm model:

$$
q_{e}=K_{F} C_{e}^{1 / n}
$$

where $C_{e}$ and $q_{e}$ are the concentrations of contaminants in water and in adsorbent at the adsorption equilibrium, respectively. $q_{m}$ is the maximum adsorption capacity; $K_{L}$ is the adsorption equilibrium constant of Langmuir model; $K_{F}$ and $n$ are Freundlich constants related to the adsorption capacity and surface heterogeneity of the adsorbents, respectively.

Figures 8 and 9 show Langmuir and Freundlich adsorption isotherm models for $\mathrm{Cr}(\mathrm{VI})$, respectively, while adsorption parameters and regression data of the models are presented in Table 1. It can be seen that both Langmuir and Freundlich isotherm models show a good fit for both raw and metal oxide impregnated CNTs. However, the value of regression coefficient $\left(R^{2}\right)$ value for Freundlich isotherm model is slightly higher than Langmuir isotherm model.

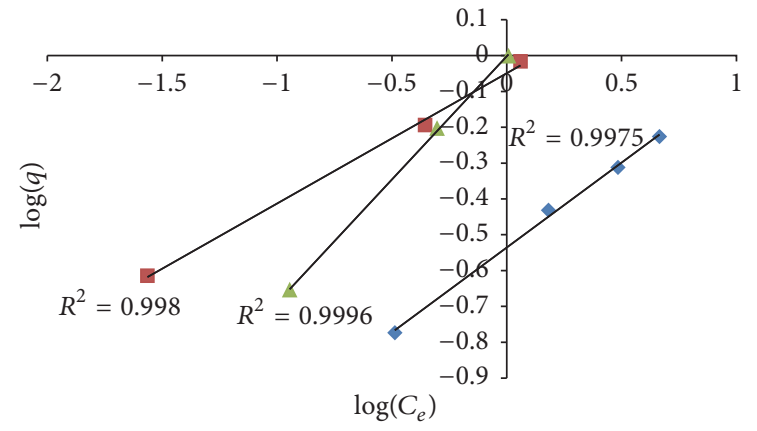

- Raw CNTs

- CNT-iron oxide

$\triangle$ CNT-aluminum oxide

FIGURE 9: Freundlich adsorption model for $\mathrm{Cr}(\mathrm{VI})$.

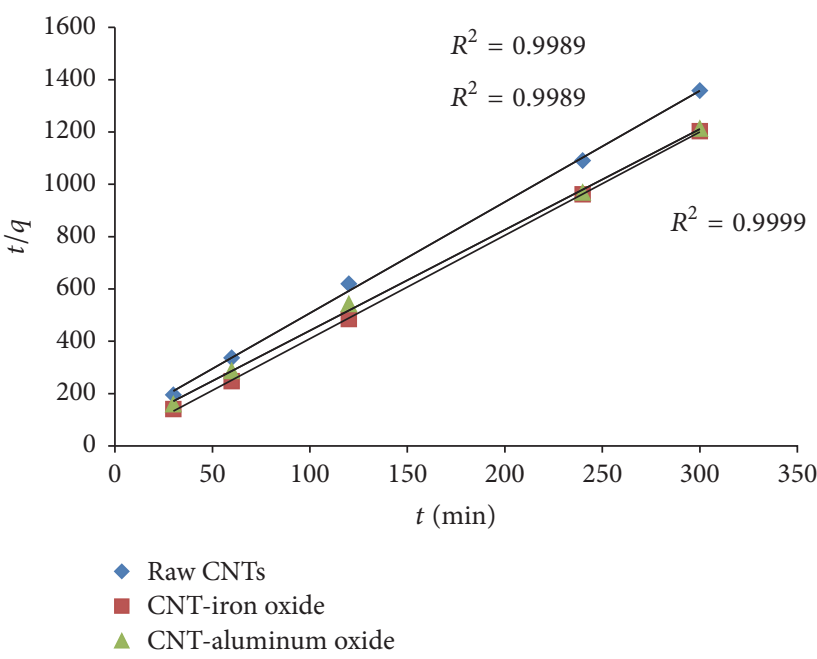

Figure 10: Pseudo-second-order kinetics for the adsorption of $\mathrm{Cr}(\mathrm{VI})$.

3.8. Kinetics Modeling. Adsorption kinetic is one of the most important factors that govern the solute uptake rate and represents the adsorption efficiency of the adsorbent. The pseudo-second-order model was used to model the kinetics of adsorption.

Representative equation of pseudo-second-order model is provided below:

$$
\frac{t}{q_{t}}=\frac{1}{k_{2} q_{e}^{2}}+\frac{t}{q_{e}} .
$$

Figure 10 represents the fitting of experimental data with the pseudo-second-order model. Table 2 provides the results of 
TABLE 2: Parameters of pseudo-second-order kinetic model for chromium.

\begin{tabular}{lccc}
\hline Adsorbent & $q_{e}(\mathrm{mg} / \mathrm{g})$ & $k_{2}\left(\mathrm{mg} \mathrm{g}^{-1} \mathrm{~min}^{-1}\right)$ & $R^{2}$ \\
\hline CNT-iron oxide & 0.253062 & 0.534162 & 0.9999 \\
CNT-aluminum oxide & 0.259575 & 0.133789 & 0.9989 \\
Raw CNTs & 0.235297 & 0.109363 & 0.9989 \\
\hline
\end{tabular}

the kinetics model fittings for the adsorption of $\mathrm{Cr}(\mathrm{VI})$ using raw and metal oxide impregnated CNTs.

It can be seen from Figure 10 and Table 2 that the correlation coefficient $\left(R^{2}\right)$ of pseudo-second-order kinetic equation is sufficiently high for all the adsorbents. Therefore, the process of $\mathrm{Cr}(\mathrm{VI})$ removal using raw and metal oxide impregnated CNTs can be well described by the pseudosecond-order model.

\section{Conclusion}

Raw, iron oxide, and aluminum oxide impregnated carbon nanotubes (CNTs) were found to be effective adsorbents for the removal of $\mathrm{Cr}(\mathrm{VI})$ ions from aqueous solution. The removal of $\mathrm{Cr}(\mathrm{VI})$ ions was strongly dependent on $\mathrm{pH}$, contact time, adsorbent dosage, and initial concentration of the $\mathrm{Cr}(\mathrm{VI})$ ions. Solution $\mathrm{pH}$ was found to be a critical parameter affecting the adsorption of $\mathrm{Cr}(\mathrm{VI})$ ions, in comparison with the other parameters. The removal of $\mathrm{Cr}(\mathrm{VI})$ ions was observed to decrease with increase in $\mathrm{pH}$ of the solution. It was observed that both CNTs impregnated with $10 \%$ of iron and aluminum oxides were able to remove almost $100 \%$ of $\mathrm{Cr}(\mathrm{VI})$ ions at solution $\mathrm{pH} 6, \mathrm{Cr}(\mathrm{VI})$ initial concentration of $1 \mathrm{mg} / \mathrm{L}$, adsorbent dosage of $200 \mathrm{mg}$, agitation speed of $200 \mathrm{rpm}$, and contact time of 4 hours. The prepared materials were found to exhibit high removal efficiency at $\mathrm{pH} 6$ suggesting their great potential in real water treatment applications.

\section{Conflicts of Interest}

The authors declare that there are no conflicts of interest regarding the publication of this paper.

\section{Acknowledgments}

The authors would like to acknowledge the support provided by the Deanship of Scientific Research (DSR) at King Fahd University of Petroleum and Minerals (KFUPM) for funding this work through Project no. IN131065.

\section{References}

[1] D. Mohan and C. U. Pittman Jr., "Activated carbons and low cost adsorbents for remediation of tri- and hexavalent chromium from water," Journal of Hazardous Materials, vol. 137, no. 2, pp. 762-811, 2006.

[2] B. M. Weckhuysen, I. E. Wachs, and R. A. Schoonheydt, "Surface chemistry and spectroscopy of chromium in inorganic oxides," Chemical Reviews, vol. 96, no. 8, pp. 3327-3349, 1996.

[3] S. Kalidhasan, M. Ganesh, S. Sricharan, and N. Rajesh, "Extractive separation and determination of chromium in tannery effluents and electroplating waste water using tribenzylamine as the extractant," Journal of Hazardous Materials, vol. 165, no. 1-3, pp. 886-892, 2009.

[4] J. R. Rao, P. Thanikaivelan, K. J. Sreeram, and B. U. Nair, "Green route for the utilization of chrome shavings (chromium-containing solid waste) in tanning industry," Environmental Science and Technology, vol. 36, no. 6, pp. 1372-1376, 2002.

[5] S. Vasudevan, G. Sozhan, S. Mohan, R. Balaji, P. Malathy, and S. Pushpavanam, "Electrochemical regeneration of chromium containing solution from metal finishing industry," Industrial and Engineering Chemistry Research, vol. 46, no. 9, pp. 28982901, 2007.

[6] A. K. Bhattacharya, T. K. Naiya, S. N. Mandal, and S. K. Das, "Adsorption, kinetics and equilibrium studies on removal of $\mathrm{Cr}(\mathrm{VI})$ from aqueous solutions using different low-cost adsorbents," Chemical Engineering Journal, vol. 137, no. 3, pp. 529-541, 2008.

[7] D. Mohan, K. P. Singh, and V. K. Singh, "Removal of hexavalent chromium from aqueous solution using low-cost activated carbons derived from agricultural waste materials and activated carbon fabric cloth," Industrial and Engineering Chemistry Research, vol. 44, no. 4, pp. 1027-1042, 2005.

[8] D. Mohan, K. P. Singh, and V. K. Singh, "Trivalent chromium removal from wastewater using low cost activated carbon derived from agricultural waste material and activated carbon fabric cloth," Journal of Hazardous Materials, vol. 135, no. 1-3, pp. 280-295, 2006.

[9] P. Miretzky and A. F. Cirelli, "Cr(VI) and Cr(III) removal from aqueous solution by raw and modified lignocellulosic materials: a review," Journal of Hazardous Materials, vol. 180, no. 1-3, pp. 1-19, 2010.

[10] F. C. Richard and A. C. M. Bourg, "Aqueous geochemistry of chromium: a review," Water Research, vol. 25, no. 7, pp. 807-816, 1991.

[11] J. Zhu, H. Gu, J. Guo et al., "Mesoporous magnetic carbon nanocomposite fabrics for highly efficient $\mathrm{Cr}(\mathrm{VI})$ removal," Journal of Materials Chemistry A, vol. 2, no. 7, pp. 2256-2265, 2014.

[12] B. Qiu, C. Xu, D. Sun et al., "Polyaniline coating on carbon fiber fabrics for improved hexavalent chromium removal," RSC Advances, vol. 4, no. 56, pp. 29855-29865, 2014.

[13] B. Qiu, C. Xu, D. Sun et al., "Polyaniline coated ethyl cellulose with improved hexavalent chromium removal," ACS Sustainable Chemistry and Engineering, vol. 2, no. 8, pp. 2070-2080, 2014.

[14] T. Karthikeyan, S. Rajgopal, and L. R. Miranda, "Chromium(VI) adsorption from aqueous solution by Hevea Brasilinesis sawdust activated carbon," Journal of Hazardous Materials, vol. 124, no. 1-3, pp. 192-199, 2005.

[15] C. Xu, B. Qiu, H. Gu et al., "Synergistic interactions between activated carbon fabrics and toxic hexavalent chromium," ECS Journal of Solid State Science and Technology, vol. 3, no. 3, pp. M1-M9, 2014.

[16] K. K. Krishnani and S. Ayyappan, "Heavy metals remediation of water using plants and lignocellulosic agrowastes," Reviews of 
Environmental Contamination and Toxicology, vol. 188, pp. 5984, 2006.

[17] M. Aliabadi, I. Khazaei, H. Fakhraee, and M. T. H. Mousavian, "Hexavalent chromium removal from aqueous solutions by using low-cost biological wastes: equilibrium and kinetic studies," International Journal of Environmental Science and Technology, vol. 9, no. 2, pp. 319-326, 2012.

[18] D. E. Kimbrough, Y. Cohen, A. M. Winer, L. Creelman, and C. Mabuni, "A critical assessment of chromium in the environment," Critical Reviews in Environmental Science and Technology, vol. 29, no. 1, pp. 1-46, 1999.

[19] E. Salazar, M. I. Ortiz, A. M. Urtiaga, and J. A. Irabien, "Equilibrium and kinetics of chromium(VI) extraction with Aliquat 336," Industrial and Engineering Chemistry Research, vol. 31, no. 6, pp. 1516-1522, 1992.

[20] K. A. Matis and P. Mavros, "Recovery of metals by ion flotation from dilute aqueous solutions," Separation and Purification Method, vol. 20, no. 1, pp. 1-48, 1991.

[21] F. Akbal and S. Camc1, "Copper, chromium and nickel removal from metal plating wastewater by electrocoagulation," Desalination, vol. 269, no. 1-3, pp. 214-222, 2011.

[22] G. Tiravanti, D. Petruzzelli, and R. Passino, "Pretreatment of tannery wastewaters by an ion exchange process for $\mathrm{Cr}$ (III) removal and recovery," Water Science and Technology, vol. 36, no. 2-3, pp. 197-207, 1997.

[23] S. Rengaraj, K.-H. Yeon, and S.-H. Moon, "Removal of chromium from water and wastewater by ion exchange resins," Journal of Hazardous Materials, vol. 87, no. 1-3, pp. 273-287, 2001.

[24] S. Rengaraj, C. K. Joo, Y. Kim, and J. Yi, "Kinetics of removal of chromium from water and electronic process wastewater by ion exchange resins: $1200 \mathrm{H}, 1500 \mathrm{H}$ and IRN97H," Journal of Hazardous Materials, vol. 102, no. 2-3, pp. 257-275, 2003.

[25] D. Petruzzelli, R. Passino, and G. Tiravanti, "Ion exchange process for chromium removal and recovery from tannery wastes," Industrial and Engineering Chemistry Research, vol. 34, no. 8, pp. 2612-2617, 1995.

[26] C. A. Kozlowski and W. Walkowiak, "Removal of chromium(VI) from aqueous solutions by polymer inclusion membranes," Water Research, vol. 36, no. 19, pp. 4870-4876, 2002.

[27] H. F. Shaalan, M. H. Sorour, and S. R. Tewfik, "Simulation and optimization of a membrane system for chromium recovery from tanning wastes," Desalination, vol. 141, no. 3, pp. 315-324, 2001.

[28] Ihsanullah, A. Abbas, A. M. Al-Amer et al., "Heavy metal removal from aqueous solution by advanced carbon nanotubes: critical review of adsorption applications," Separation and Purification Technology, vol. 157, pp. 141-161, 2016.

[29] L. Monser and N. Adhoum, "Modified activated carbon for the removal of copper, zinc, chromium and cyanide from wastewater," Separation and Purification Technology, vol. 26, no. 2-3, pp. 137-146, 2002.

[30] D. Park, Y.-S. Yun, J. Y. Kim, and J. M. Park, "How to study $\mathrm{Cr}(\mathrm{VI})$ biosorption: use of fermentation waste for detoxifying $\mathrm{Cr}(\mathrm{VI})$ in aqueous solution," Chemical Engineering Journal, vol. 136, no. 2-3, pp. 173-179, 2008.

[31] M. Ulmanu, E. Marañón, Y. Fernández, L. Castrillón, I. Anger, and D. Dumitriu, "Removal of copper and cadmium ions from diluted aqueous solutions by low cost and waste material adsorbents," Water, Air, and Soil Pollution, vol. 142, no. 1-4, pp. 357-373, 2003.
[32] M. Aliabadi, K. Morshedzadeh, and H. Soheyli, "Removal of hexavalent chromium from aqueous solution by lignocellulosic solid wastes," International Journal of Environmental Science and Technology, vol. 3, no. 3, pp. 321-325, 2006.

[33] V. K. Singh and P. N. Tiwari, "Removal and recovery of chromium (VI) from industrial waste water," Journal of Chemical Technology and Biotechnology, vol. 69, no. 3, pp. 376-382, 1997.

[34] S. K. Srivastava, R. Tyagi, and N. Pant, "Adsorption of heavy metal ions on carbonaceous material developed from the waste slurry generated in local fertilizer plants," Water Research, vol. 23, no. 9, pp. 1161-1165, 1989.

[35] E. Demirbas, M. Kobya, E. Senturk, and T. Ozkan, "Adsorption kinetics for the removal of chromium (VI) from aqueous solutions on the activated carbons prepared from agricultural wastes," Water SA, vol. 30, no. 4, pp. 533-539, 2004.

[36] D. D. Das, R. Mahapatra, J. Pradhan, S. N. Das, and R. S. Thakur, "Removal of $\mathrm{Cr}(\mathrm{VI})$ from aqueous solution using activated cow dung carbon," Journal of Colloid and Interface Science, vol. 232, no. 2, pp. 235-240, 2000.

[37] S. Bosinco, J. Roussy, E. P. Guibal, and P. L. Cloirec, "Interaction mechanisms between hexavalent chromium and corncob," Environmental Technology, vol. 17, no. 1, pp. 55-62, 1996.

[38] P. Candela, J. M. M. Martinez, and R. T. Macia, "Chromium(VI) removal with activated carbons," Water Research, vol. 29, pp. 2174-2180, 1995.

[39] A. M. El-Kamash, A. A. Zaki, and M. A. El Geleel, "Modeling batch kinetics and thermodynamics of zinc and cadmium ions removal from waste solutions using synthetic zeolite A," Journal of Hazardous Materials, vol. 127, no. 1-3, pp. 211-220, 2005.

[40] G. Cimino, A. Passerini, and G. Toscano, "Removal of toxic cations and $\mathrm{Cr}(\mathrm{VI})$ from aqueous solution by hazelnut shell," Water Research, vol. 34, no. 11, pp. 2955-2962, 2000.

[41] M. Kobya, "Adsorption, kinetic and equilibrium studies of $\mathrm{Cr}(\mathrm{VI})$ by hazelnut shell activated carbon," Adsorption Science and Technology, vol. 22, no. 1, pp. 51-64, 2004.

[42] K. K. Singh, R. Rastogi, and S. H. Hasan, "Removal of cadmium from wastewater using agricultural waste 'rice polish", Journal of Hazardous Materials, vol. 121, no. 1-3, pp. 51-58, 2005.

[43] D. C. Sharma and C. F. Forster, "Removal of hexavalent chromium using sphagnum moss peat," Water Research, vol. 27, no. 7, pp. 1201-1208, 1993.

[44] S. H. Lee, C. H. Jung, H. Chung, M. Y. Lee, and J.-W. Yang, "Removal of heavy metals from aqueous solution by apple residues," Process Biochemistry, vol. 33, no. 2, pp. 205-211, 1998.

[45] C. K. Lee, K. S. Low, and K. L. Kek, "Removal of chromium from aqueous solution," Bioresource Technology, vol. 54, no. 2, pp. 183-189, 1995.

[46] K. S. Low, C. K. Lee, and A. Y. Ng, "Column study on the sorption of $\mathrm{Cr}(\mathrm{VI})$ using quaternized rice hulls," Bioresource Technology, vol. 68, no. 2, pp. 205-208, 1999.

[47] W. Jianlong, "Removal of Cr(VI) from aqueous solution by coal flyash adsorption I: characteristics of chromium adsorption on flyash," Toxicological and Environmental Chemistry, vol. 68, no. 1-2, pp. 53-62, 1999.

[48] M. Dakiky, M. Khamis, A. Manassra, and M. Mer'eb, "Selective adsorption of chromium(VI) in industrial wastewater using low-cost abundantly available adsorbents," Advances in Environmental Research, vol. 6, no. 4, pp. 533-540, 2002. 
[49] N. K. Hamadi, X. D. Chen, M. M. Farid, and M. G. Q. Lu, "Adsorption kinetics for the removal of chromium(VI) from aqueous solution by adsorbents derived from used tyres and sawdust," Chemical Engineering Journal, vol. 84, no. 2, pp. 95105, 2001.

[50] K. Selvi, S. Pattabhi, and K. Kadirvelu, "Removal of Cr(VI) from aqueous solution by adsorption onto activated carbon," Bioresource Technology, vol. 80, no. 1, pp. 87-89, 2001.

[51] S. S. Shukla, J. Y. Li, K. L. Dorris, and A. Shukla, "Removal of nickel from aqueous solutions by sawdust," Journal of Hazardous Materials, vol. 121, no. 1-3, pp. 243-246, 2005.

[52] C. Selomulya, V. Meeyoo, and R. Amal, "Mechanisms of Cr(VI) removal from water by various types of activated carbons," Journal of Chemical Technology and Biotechnology, vol. 74, no. 2, pp. 111-122, 1999.

[53] H. Farrah and W. F. Pickering, "The sorption of lead and cadmium species by clay minerals," Australian Journal of Chemistry, vol. 30, no. 7, pp. 1417-1422, 1977.

[54] W. T. Tan, S. T. Ooi, and C. K. Lee, "Removal of chromium(VI) from solution by coconut husk and palm pressed fibres," Environmental Technology, vol. 14, no. 3, pp. 277-282, 1993.

[55] K. Periasamy, K. Srinivasan, and P. R. Muruganan, "Studies on chromium(VI) removal by activated ground nut husk carbon," Indian Journal of Environmental Health, vol. 33, pp. 433-439, 1991.

[56] M. S. Mansour, M. E. Ossman, and H. A. Farag, "Removal of Cd (II) ion from waste water by adsorption onto polyaniline coated on sawdust," Desalination, vol. 272, no. 1-3, pp. 301-305, 2011.

[57] M. Ayoma, T. Sugiyama, S. Doi, N. S. Cho, and H. E. Kim, "Removal of Hexavalent chromium from dilute aqueous solution by coniferous leaves," Holzforschung, vol. 53, no. 4, pp. 365$368,1999$.

[58] D. C. Sharma and C. F. Forster, "The treatment of chromium wastewaters using the sorptive potential of leaf mould," Bioresource Technology, vol. 49, no. 1, pp. 31-40, 1994.

[59] L. Dupont and E. Guillon, "Removal of hexavalent chromium with a lignocellulosic substrate extracted from wheat bran," Environmental Science and Technology, vol. 37, no. 18, pp. 42354241, 2003.

[60] Z. Reddad, C. Gerente, Y. Andres, and P. Le Cloirec, "Adsorption of several metal ions onto a low-cost biosorbent: kinetic and equilibrium studies," Environmental Science and Technology, vol. 36, no. 9, pp. 2067-2073, 2002.

[61] A. C. A. Da Costa and F. P. De França, "Cadmium uptake by biosorbent seaweeds: adsorption isotherms and some process conditions," Separation Science and Technology, vol. 31, no. 17, pp. 2373-2393, 1996.

[62] Y. Nakano, M. Tanaka, Y. Nakamura, and M. Konno, "Removal and recovery system of hexavalent chromium from waste water by tannin gel particles," Journal of Chemical Engineering of Japan, vol. 33, no. 5, pp. 747-752, 2000.

[63] D. Kratochvil, P. Pimentel, and B. Volesky, "Removal of trivalent and hexavalent chromium by seaweed biosorbent," Environmental Science and Technology, vol. 32, no. 18, pp. 2693-2698, 1998.

[64] M. E. A. Ali, "Synthesis and adsorption properties of chitosanCDTA-GO nanocomposite for removal of hexavalent chromium from aqueous solutions," Arabian Journal of Chemistry, In press.
[65] N. Calace, A. Di Muro, E. Nardi, B. M. Petronio, and M. Pietroletti, "Adsorption isotherms for describing heavy-metal retention in paper mill sludges," Industrial and Engineering Chemistry Research, vol. 41, no. 22, pp. 5491-5497, 2002.

[66] C.-H. Weng, C. P. Huang, H. E. Allen, and P. F. Sanders, "Cr(VI) adsorption onto hydrous concrete particles from groundwater," Journal of Environmental Engineering, vol. 127, no. 12, pp. 11241131, 2001.

[67] S. S. Ahluwalia and D. Goyal, "Removal of heavy metals by waste tea leaves from aqueous solution," Engineering in Life Sciences, vol. 5, no. 2, pp. 158-162, 2005.

[68] V. Sarin and K. K. Pant, "Removal of chromium from industrial waste by using eucalyptus bark," Bioresource Technology, vol. 97, no. 1, pp. 15-20, 2006.

[69] M. H. Dehghani, D. Sanaei, I. Ali, and A. Bhatnagar, "Removal of chromium(VI) from aqueous solution using treated waste newspaper as a low-cost adsorbent: kinetic modeling and isotherm studies," Journal of Molecular Liquids, vol. 215, pp. 671679, 2016.

[70] A. S. K. Kumar, S. S. Kakan, and N. Rajesh, "A novel amine impregnated graphene oxide adsorbent for the removal of hexavalent chromium," Chemical Engineering Journal, vol. 230, pp. 328-337, 2013.

[71] Ihsanullah, F. A. Al-Khaldi, B. Abusharkh et al., "Adsorptive removal of cadmium(II) ions from liquid phase using acid modified carbon-based adsorbents," Journal of Molecular Liquids, vol. 204, pp. 255-263, 2015.

[72] Ihsanullah, H. A. Asmaly, T. A. Saleh, T. Laoui, V. K. Gupta, and M. A. Atieh, "Enhanced adsorption of phenols from liquids by aluminum oxide/carbon nanotubes: comprehensive study from synthesis to surface properties," Journal of Molecular Liquids, vol. 206, pp. 176-182, 2015.

[73] Ihsanullah, F. A. Al-Khaldi, B. Abu-Sharkh et al., "Effect of acid modification on adsorption of hexavalent chromium (Cr(VI)) from aqueous solution by activated carbon and carbon nanotubes," Desalination and Water Treatment, vol. 57, no. 16, pp. 7232-7244, 2016.

[74] H. A. Asmaly, B. Abussaud, Ihsanullah, T. A. Saleh, V. K. Gupta, and M. A. Atieh, "Ferric oxide nanoparticles decorated carbon nanotubes and carbon nanofibers: from synthesis to enhanced removal of phenol," Journal of Saudi Chemical Society, vol. 19, no. 5, pp. 511-520, 2015.

[75] H. A. Asmaly, B. Abussaud, Ihsanullah et al., "Evaluation of micro- and nano-carbon-based adsorbents for the removal of phenol from aqueous solutions," Toxicological and Environmental Chemistry, vol. 97, no. 9, pp. 1164-1179, 2015.

[76] A. Abbas, B. A. Abussaud, Ihsanullah, N. A. H. Al-Baghli, M. Khraisheh, and M. A. Atieh, "Benzene removal by iron oxide nanoparticles decorated carbon nanotubes," Journal of Nanomaterials, vol. 2016, Article ID 5654129, 10 pages, 2016.

[77] Ihsanullah, A. M. Al Amer, T. Laoui et al., "Fabrication and antifouling behaviour of a carbon nanotube membrane," Materials and Design, vol. 89, pp. 549-558, 2016.

[78] J. Zhu, S. Wei, H. Gu et al., "One-pot synthesis of magnetic graphene nanocomposites decorated with core@double-shell nanoparticles for fast chromium removal," Environmental Science and Technology, vol. 46, no. 2, pp. 977-985, 2012.

[79] C. J. Lin, S. L. Wang, P. M. Huang et al., "Chromate reduction by zero-valent Al metal as catalyzed by polyoxometalate," Water Research, vol. 43, no. 20, pp. 5015-5022, 2009. 
[80] J. Hu, C. Chen, X. Zhu, and X. Wang, "Removal of chromium from aqueous solution by using oxidized multiwalled carbon nanotubes," Journal of Hazardous Materials, vol. 162, no. 2-3, pp. 1542-1550, 2009.

[81] H. Ding, X. Li, J. Wang, X. Zhang, and C. Chen, "Adsorption of chlorophenols from aqueous solutions by pristine and surface functionalized single-walled carbon nanotubes," Journal of Environmental Sciences, vol. 43, pp. 187-198, 2016. 

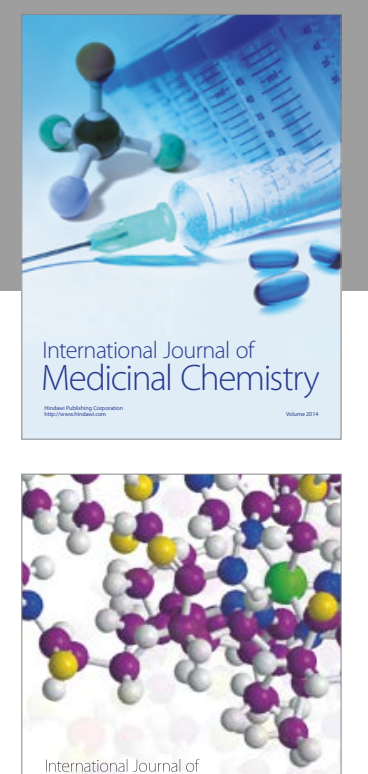

Carbohydrate Chemistry

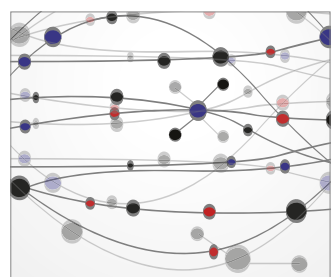

The Scientific World Journal
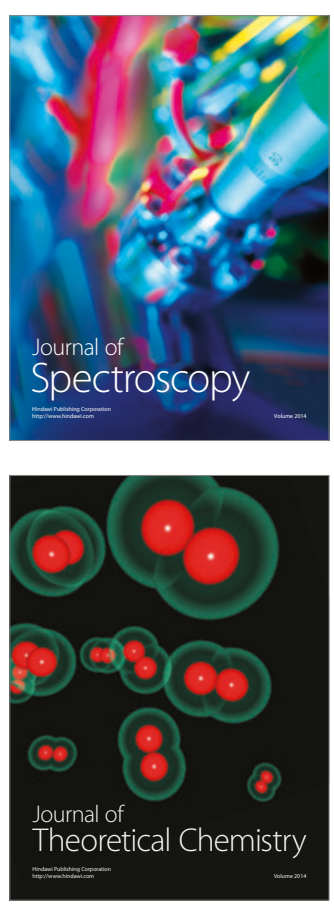
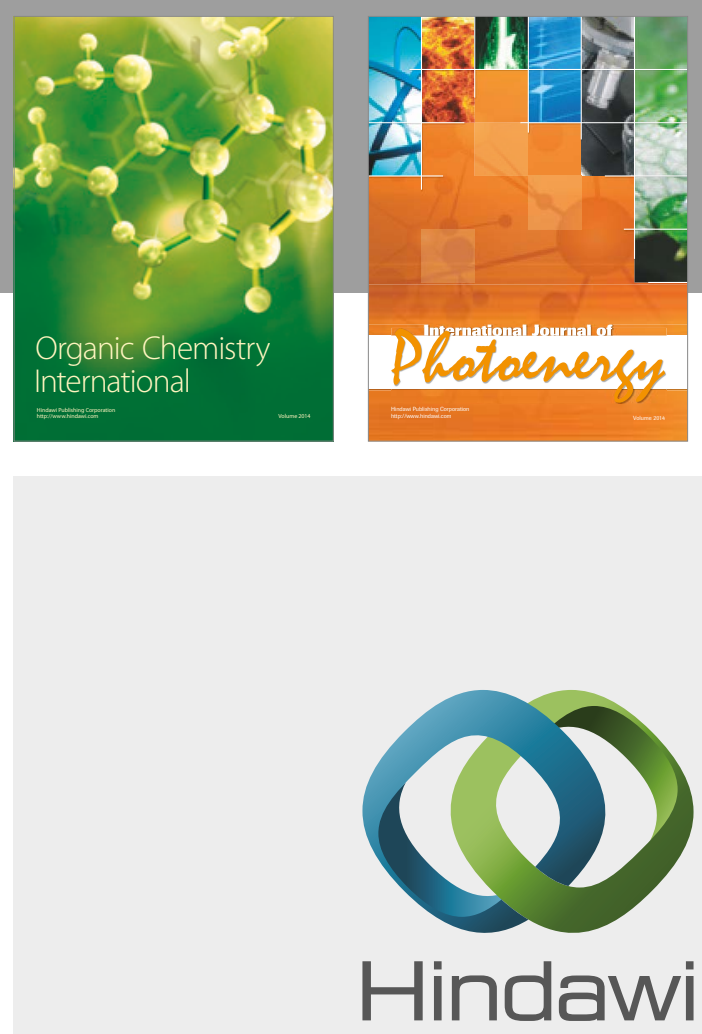

Submit your manuscripts at

https://www.hindawi.com

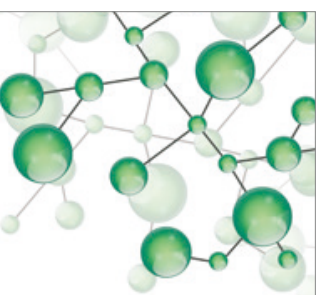

International Journal of

Inorganic Chemistry

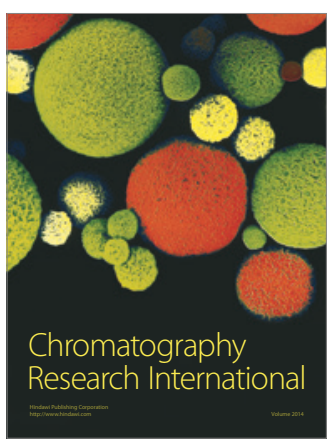

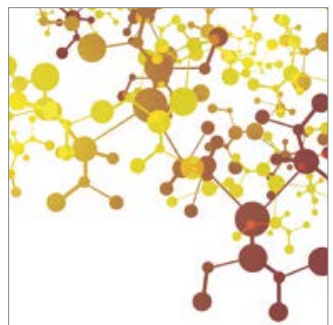

Applied Chemistry
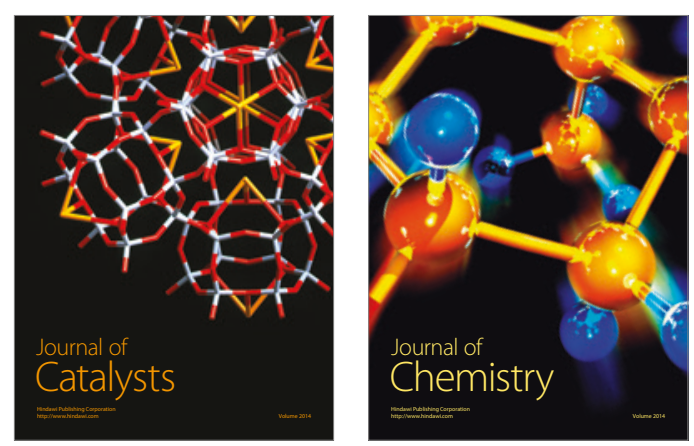
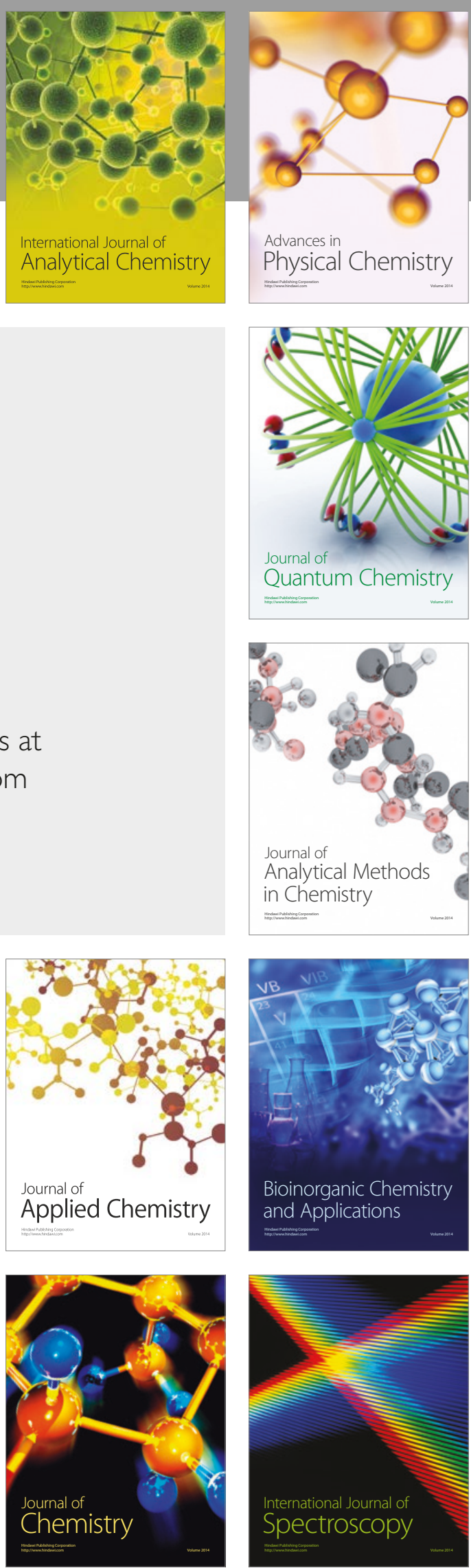